\section{Teaching Bahasa Indonesia for Polish Speakers Based on Moderate Muslim Culture}

\author{
1 Jauharoti Alfin \\ 1 UIN Sunan Ampel, Indonesia
}

\begin{abstract}
The purpose of this paper is to explain the result of moderate Muslim culture immersion model development into the Bahasa Indonesia untuk Penutur Asing (Bahasa Indonesia for Non-Native Speakers [BIPA]) program in the faculty of New Philology, Adam Mickiewicz University in Poznan, Poland. The focus of the development is the research and development (R\&D) stage, which comprises: preliminary study, development, and testing. This study uses the before-after comparative analysis method on an experimental group with a control group. It is concluded that the model is succeeded in significantly improving the understanding of the BIPA program's students on moderate Muslim culture.
\end{abstract}

\section{Keywords}

Bahasa Indonesia

Poland

moderate muslim culture

\section{Ethical Lingua}

Vol. 7, No. 1, 2020

ISSN 2355-3448 (Print)

ISSN 2540-9190 (Online)

Corresponding Email

Jauharoti Alfin

alfin@uinsby.ac.id

Article's History

Submitted 11 Nov 2019

Revised 26 February 2020

Accepted 31 March 2020

DOI

10.30605/25409190.125

Copyright (๑) 2020

The Author(s)

This article is licensed under CC BY-NC-SA 4.0 License

\section{(cc) EY-NC-SA}




\section{Teaching Bahasa Indonesia for Polish Speakers Based on Moderate Muslim Culture}

Questions asked by the master's students in the Institute of Linguistics, Adam Mickiewicz University in Poznan, Poland, shocked the author. They asked questions such as: "Is Indonesia safe from the influence of ISIS/Islamic State of Iraq and Syria?" and "Is the information about a certain number of Indonesian who join ISIS true?" Implicitly, those questions give an important indication that Poland educated middle class, especially among University students, have received negative information about radicalism and terrorism in Indonesia.

It is difficult to be denied that radicalism in Indonesia has increased post-reform (Fealy, 2004). There were even a small number of Muslim activists in Indonesia become ISIS (Islamic State of Iraq and Syria) sympathizer and migrate to Iraq and Syria to join ISIS. However, their actions less or perhaps does not give any effects to the diversity of the majority moderate Islam in Indonesia and anticipated by the government and mainstream Islamic organizations to reduce the symptoms of growing radicalism in Indonesia (Affandi, Dermawan, \& Alam, 2019; Adnan, 2016). Unlike the Middle Eastern countries, the diversity of religions, races, and skin colors that exist in Indonesia is identity, so there needs to be an effort to change the understanding of western society about how Muslim thought in Indonesia in general. This can be shown from the perspective of 'santri' about their disapproval of the existence of symptoms of radicalism in Indonesia (Sodiq \& Astuti, 2019) and how some branches of Islam in Indonesia already has a foundation that cannot be entered by radicalism (Azwar, 2018).

As foreign university students who have adequate facilities to access information written in Bahasa Indonesia, the questions above are understandable. They can found various virtual sources easily, including the ones that are managed by radical Muslim activists and terrorists about ISIS development in Indonesia. Moreover, they can found news related to the terror that happened on MH Tamrin street on 14 January 2016 easily. At the same time, it is difficult for them to find virtual resources that describe the dynamic of moderate Islam in Indonesia deeply. Many of them have not been to Indonesia and have not experienced the praxis of the majority of Muslim in Indonesia directly.

Bahasa Indonesia for Non-Native Speakers (BIPA) can be one of the instruments to reconstruct the knowledge of Poland University students about radicalism, terrorism, and ISIS in Indonesia. This is consistent with the transformation of BIPA in many countries in the world which has two purposes, making Bahasa Indonesia as one of the international languages and global campaign of the national culture universalism. One of the important aspects of national culture is the growth and survival of moderate Islam as the paradigm of the Muslim majority in Indonesia for centuries.

Therefore, the research on the BIPA program refers to the development of learning strategies (Ariani, 2019; Kusuma, 2018; Purwiyanti, Suwandi, \& Andayani, 2017; Sari, Suwandi, \& St Y, 2017). Yet, no research has been found that refers to the use of the BIPA program, which focuses on both the content of the discussion and the impact of the content discussed on the paradigm shift of the research subjects. 
This study is expected to contribute to the development of BIPA program learning models. Foreign speakers are expected not only to understand how to speak Indonesian and understand textually about Indonesian culture but also understand the socio-cultural conditions that exist in Indonesia society, especially moderate Muslim communities that mostly exist in Indonesia. The purpose of this research is to understand the results of the development of learning models in BIPA programs based on moderate Islamic culture in Poland.

\section{Method}

Based on the important role of BIPA as explained above, the development of BIPA model that constructs the knowledge about radicalism and terrorism in Indonesia is needed. The model development that is referred to is the arrangement of BIPA learning design based on moderate Islamic culture. This design is implemented through research and development activities with the students of Indonesian-Malayan Philology, in the department of Institute of Linguistics, New Philology faculty, Adam Mickiewicz University in Poznan, Poland as the subjects.

In the beginning, the model development was planned to refer to Borg \& Gall's ten steps. The ten steps are: 1) gathering information and relevant research result with the focus of research and information collecting; 2) planning the research; 3) develop a preliminary form of product; 4) doing preliminary field testing; 5) doing main product revision that is based on the preliminary trials. 6) main field testing; 7) operational product revision; 8) operational field testing; 9) final product revision; and 10) dissemination and implementation (Borg \& Gall, 1983). However, as it was trialed by Soekmadinata, aside from the need for a quite significant resource, the ten steps were also not practical when it requires to implement them step by step (Sukmadinata, 2013). With this consideration, the model development was being modified into three main steps; they were: 1) preliminary study; 2) development; and 3) testing.

\section{Results \& Discussion}

\section{BIPA, Cultural Diplomacy and Moderate Muslim}

In research and development, one of the important steps is to do a preliminary study that covers the search of various literature related to BIPA and moderate Muslims. This study was done to "find out theoretically based concepts which strengthen a product" (Sukmadinata, 2013). Based on the result of the research, BIPA transformation in various countries has a strategic role as cultural diplomacy. Other than that, the literature study also gives an important clue on the big chance of moderate Muslims and its culture as one of the pillars in BIPA learning program abroad.

Historically, BIPA program in various countries can be tracked since the mid-nineteenth century. At that time, BIPA had been an important field of study in the Netherland (Rivai, Mariani, Neswita, \& Saptawuryandari, 2010). Over the years, BIPA becomes the second language that is studied in many countries.

BIPA program is designed as part of cultural diplomacy in the international world. Many studies have mentioned that cultural diplomacy is referred to the exchange of ideas, information, value system, tradition, belief, and other aspects which are part of the culture 
between different countries and between different citizens with the frame of understanding each other. It is consistent with the definition stated by Harnhisel, who said that:

"cultural diplomacy, most commonly defined as the exchange of ideas, information, value systems, traditions, beliefs and other aspects of culture among nations and their peoples in order to foster mutual understanding" (Barnhisel, 2015).

Table 1

The History of BIPA Acceptance in Many Countries

\begin{tabular}{ll}
\hline Countries & BIPA Acceptance Year \\
\hline The United States & 1880 s \\
Australia & 1959 (university); \\
& 1964 (senior high shool) \\
The United Kingdom & 1967 \\
Japan & 1908 \\
Germany & 1931 \\
South Korea & 1964 \\
France & 1841 \\
The Republic of China & 1950 \\
\hline
\end{tabular}

(Rivai, Mariani, Neswita, \& Saptawuryandari, 2010).

BIPA, as part of the cultural diplomacy, has been confirmed by Agus Sartono when he was the head of Planning and Foreign Cooperation bureau. He said that BIPA program is the manifestation of the cultural diplomacy of Indonesian government with foreign university students as the focus. Through this program, it is hoped that the knowledge, attitude, and behavior of foreign University students are formed to be able to express the diversity of Indonesian culture and religion to the international world, especially to their own countries (Diplomasi Seni, 2010).

The success of this transformation to the foreign university students could be one of the soft power diplomacy assets and become one of Indonesian diplomacy strategies so that the international world does not only recognize Indonesia from its democracy and economy power. Soft power diplomacy is understood as power practice that has the strength to acknowledge different countries or citizens through non-violent ways or without military, politic, and economic help. Nye said that soft power diplomacy refers to the ability of a country or citizens to lead or to agree to the wish of a particular country without any coercion. Nye said that "soft power is our ability to get what we want through attraction rather than coercion" (Rosendorf, 2000). It is important to note that politics always presupposes that there are countries different values that depend on its credibility on the eyes of other countries; meanwhile, economics always tucks profit-and-loss calculation; and conversely, culture has a universal language. 
The problem now is that there are other aspects of Indonesian national culture which have not been touched by BIPA program. Moderate Muslim culture is one of the materials that has not been included in the program. Whereas, moderate Muslim culture transformation could be the counter-culture in the middle of news flare in the international world, which announces that Indonesia is one of the countries that contribute to global terrorism. Besides that, moderate Muslim culture as the primary material could also support global campaign about tolerance dynamic and inclusivism in Indonesia, which has been done much during these times, especially by the government elites through the cross-countries' formal meetings.

Moderate muslim is the majority in population in Indonesia and could be said to represent Islam in Indonesia. Of course, moderate muslim as the majority of Islam have an independent religious culture, which becomes the important pillar of national culture. Moderate muslim refers to the follower of Islam whose religious attitude always puts forward and honor inclusivism and pluralism. They strongly reject any forms of religious exclusivism.

Exclusivism is understood as islamic religious culture, which is based on the principals that Islam is the only legitimate way toward salvation. Exclusive muslim, therefore, does not differentiate between the salvific presence and the activities in other religion's tradition, and the salvific presence and Allah's activities as Islam as a whole. On the contrary, inclusivism refers to Islam as the only true religious culture compares to other religions. However, this culture also recognizes that there is righteousness in other religions. It is just, all the righteousness in other religions are basically refers to Islam. Meanwhile, pluralism, which is mostly being equaled to "parallelism" presupposes religiosity that rests on the belief that every religion besides Islam has their own salvation way. Therefore, the claim that Islam is the only way (exclusive), or Islam is the complement way (inclusive) needs to be declined (Rachman, 2004).

Moderate muslim religious cultural transformation, which is inclusive and pluralistic, is very important to be done through BIPA program. Most of the countries that have Bahasa Indonesia program can be ensured to have non-muslim citizens as the majority, particularly countries in the European region such as Poland, Germany, England, and France. As nonmuslim population, they tend to be sensitive and have negative perceptions towards Indonesian religious dynamics, which they understand as harming other religious followers such as the Catholics and Christians. Many violent actions towards religious minorities, radicalism and terrorism, are tended to be understood as Inseparable from Islam as a whole. This phenomenon, of course, could implicate the failure of cultural diplomacy that has been developed in many ways, including BIPA program. However, at the same time, some opportunities are available for BIPA to be an important instrument for religious cultural transformation, which is real, being present, and happens in the public space.

\section{The Analysis of Model Development Needs}

Needs assessment is needed to determine the most relevant products to be developed (Sukmadinata, 2013). Based on the data which has been obtained, the product about to produce is BIPA learning design based on moderate Muslim culture. The culture refers to the tradition and pattern behavior with religious life which put forward and is based on inclusive attitude and pluralistic (parallelism). Through this product, moderate Muslim culture diversity will be immersed into the learning of Bahasa Indonesia with the topic of 
"Paragraph dalam Bahasa Indonesia" ("Paragraph in Bahasa Indonesia) for foreign University students in the Indonesian-Malayan Philology study program, Institute of Linguistics major, New Philology faculty, Adam Mickiewicz University in Poznan, Poland.

The development of the product above is based on the reality that foreign university students of BIPA program in Poland mostly have negative perceptions about religious dynamics in Indonesia. This perception is strengthened by the foreign policy in several countries, which once issued a travel warning for its citizens not to travel to Indonesia.

Stelmachowska, a Polish woman who is one of Bahasa Indonesia lecturer, said that many violent actions and minority oppression had formed the understanding of Polish university students that "the beauty of Indonesian face as a tolerant country is fading." They tend to relate Islam with radicalism with "the action or militant movement which is anti-western and always chaotic when doing democracy." Furthermore, she affirms that "in the last few years, radical Islamic groups have been successful in changing the face of Indonesian Islam into an aggressive, violent, intolerant, and full of hatred." The phenomenon of Islam radicalism in Indonesia has made the university students of BIPA program in Poland worried (Stelmachowska, 2016).

Religious situation, which is worsening and is caused by radicalism and Islamic terrorism in Indonesia, is also strengthened by Palandi, an Indonesian BIPA lecturer. The Bahasa Indonesian proficiency of university students of Indonesian-Malayan Philology study program makes it possible for them to access information that relates to the current situation in Indonesia. As a consequence, besides having sufficient understanding of the dynamic of politics, social, cultural, and security, and based on the information access written in Bahasa Indonesia, they conclude that "movement issue, network, and fundamentalism teachings and Islam radicalism have been infiltrated in Indonesia." Moreover, the Polish students of BIPA program also receive the news about "movement and terrorism network that have been infiltrating into the religious education, and it frightens them" (Palandi, 2016).

Teja Gumilar, an Indonesian BIPA lecturer, also has the same view. Islamic radicalism phenomenon in Indonesia, he thinks, has been successful in building deep anxiety for University students in Poland. He describes that:

Religious radicalism in Indonesia is better known as Islamic radicalism. As the country with the most Muslim population in the world, Indonesia has often been the focus of the news in Poland, especially in the middle of the hectic news about Middle East Muslim immigrant crisis situation which flooding Europe, armed conflict in Iraq, Syria, and Sudan, and also the emerging worrisome ISIS threats. All UAM (Univesity of Adam Mickiewicz) students often ask about religious radicalism in Indonesia, considering the Bali Bomb in 2002 and 2005, sharia phenomenon in Aceh, and also Front Pembela Islam's (FPI) actions (Gumilar, 2016).

The counter-discourse efforts have been made many times, especially by the Indonesian BIPA lecturers in Poland. However, the counter-discourse was reactive; for example, answering students' questions during the lectures. The solution has not been found, on how to integrate moderate Muslim culture into the learning design. On the other hand, culture introduction has been done through video playback and live demonstrations such as batik, angklung, shadow puppet, plate dance, saman dance, songket, and wayang golek (puppet show) (Darmayanti, 2013). When, in fact, moderate Muslim culture is one of the national 
cultures that have an opportunity to be transformed through BIPA learning. It does not mean that national cultural aspects such as art and traditional dance that have been taught need to be eliminated.

\section{Designing the Model Draft}

This step focuses on the development activities of the product preliminary form. This preliminary product is tentative and the chance of it to be developed through a set of trialsand-errors activities is opened (Sukmadinata, 2013). In this research, the preliminary product is in the form of learning design which is intended to be trialed limitedly. To produce relevant design and able to answer the needs, the first step that was done is to determine what competence that is wanted to be reached. There are two competencies that the students need to accomplish; they are: 1) the skill in understanding variety of paragraph, the requirements to form them, and their structures in texts written in Bahasa Indonesia; 2) the skill to identify, to find, and to map the inclusive and pluralistic moderate Muslim culture in the text written in Bahasa Indonesia.

The second step to arrange the preliminary product is to formulate the lecture syllabus. Referring to the target competencies, every sub-component of the syllabus always encloses two aspects; they are Bahasa Indonesia skills and moderate Muslim culture. As an example, the competency indicator is "BIPA program students are able to identify the elements of paragraph development in a text." To reach the indicators, the topic that is needed to be learned consists of 1) cohesion element; 2) coherence element; 3) development element; and 4) tolerant religious culture in the text's content as the teaching materials.

Appropriate materials are needed to ease the students in producing competence indicator achievement. Learning materials used are media reportage, which discusses themes related to the development of the product. Learning materials is understood as "any materials used to help teachers/instructors in doing the teaching and learning activities," both in the written and unwritten forms" (Depdiknas, Panduan Pengembangan Bahan Ajar, 2008).

Choosing the media reportage as learning materials with a balance point of view, the content being discussed is presupposed the real facts or events. It is important to ensure foreign students of BIPA in Poland, who are in majority have not been to Indonesia. The topics chosen are based on the needs and are supportive in reaching the competence targeted. The topics are not only related to Bahasa Indonesia, but also related to moderate muslim culture in Indonesia.

Before it is tested, syllabus formula and selected learning materials are evaluated through desk try out/ desk evaluation in the next step (Sukmadinata, 2013). This is to measure the appropriateness of the products. Some of the legal experts were involved in the process. Azyumardi Azra and Amin Abdullah were two experts who had the roles in evaluating the theoretical base which was used in the research. As for the praxis appropriateness, the preliminary products were evaluated by the BIPA lecturers in the Indonesian-Malayan Philology study program, Institute of Linguistics major, New Philology faculty, Adam Mickiewicz University in Poznan, Poland. Two Polish lecturers were involved in the appropriateness assessment activity; they were: Daria Zozula and Dorotea Moni Stelmachowska. The two Indonesian lecturers are Desy Teja Gumilar and Esther Hesline Palandi. 


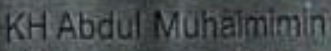 Kerap Shalat di Katedral}

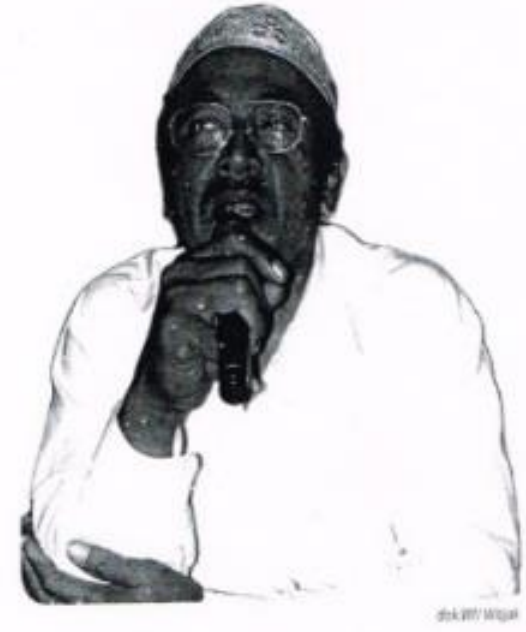

KINI mulai sulit menemukan agamawan seperti KH Abdul Muhaimin. Pengasuh PP Nurul Ummahat, Kota Gede, Yogyakarta. ini sering memfasilitasi kegiatan antar agama, ba k Islam. Kristen, Katolik, Buddha, Konghucu, Hindu, dan sebagainya di Forum Persaudaraan Umat Beriman (FPUB) yang dipimpinnya.

Apa yang melatari sikap keterbukaannya? " Ini hablun min alnos yang intinya moralitas dan humanitas. Pada aspek ini semua orang bisa ketemu, "vjar alumni PP Krapyak Yogyakarta ini kepada Nurul Huda Maarif dari the WAHID Institute.

Karenanya, Kiai Muhaimin berpesan, jika bergaul dengan penganut agama lain jangan sekall-kali menyinggung masalał teologis. "Ini riskan. Nanti urung-unung (belum apa-apa, red.) dicap kafit. Teologi itu masing-masing, lakum dinukum weliva din'katanya.

'Yang saya lakukan inil lebih ke aspek humanisme," imbuh anggota Dewan Pembina indonesian Conference on Religion and Peace (ICRP) ini.

la pernah menjalin kerja sama dengan Yayasan Buddhe Suci, sebuah organisasi sosial beranggotakan penganut Buddha untuk program penanaman sejuta pohon Mahoni. Bentuk kerja sama itu, imbuhnya, bibit disediakan Buddha Suci dan pengelo. laan lapangan ditangani dirinya dibantu Lakpesdam NU Yog: yakarta. "Baru 100 ribu pohon akan ditanam di lereng Merapl. Plyungan, dan Bantul,"katanya.

Pria kelahiran Kotagede 13 Maret 1953 ini aktif ceramah didesa-desa yang mayoritas penduduknya non-muslim. "Saya ceramah ke grass root, tidak ke elit. Tidak hanya di desa muslim. juga desa nonmuslim," imbuh penerima Tasrif Award tahun 2000 dari Aliansi Jumalis independen.

Saking intensifnya mengikuti dialog lintas iman, tak jarang ritual shalat dijalankan Kiai Muhaimin di tempat peribadatan nonmuslim. 'Kalau saya nginep di Katedral shalatnya yo di Katedral,'kata mantan aktivis GP Ansor ini. 'Di Yogya sudah tahu semua, kalau waktu shalat, saya akan shalat di manapun. Karena Jiliat al-ardhu mosjidan. Bumi seluruhnya dijadikan sebagai tempat shalat" katanya mengutip sabda Nabi SAW.

'Tapi saya tidak shalat di altar gerela, jelas anggota Dewan Kebudayaan Or ini

Bahkan putera KH Marzuki ini menyilahkan nonmuslim untuk menginap di pesantrennya. "Banyak suster nginep di pesantren saya untuk mengenal Islam. Belum lama juga ada peneliti dari Universitas Berkeley di AS, India, Amerika, Cina, Korea, Roma dan Jepang," ujarnya.

Karena keterbukaannya, Anggota MUI DiY bidang Kerukun an ini kerap dinilai kontroversial, terutama oleh banyak tokoh NU. "Beda pandangan iku gaweane wong NU. Saya sendiri tidak punya pretensi semua harus berpandangan sama dengan saya;" tegas salah satu pemrakarsa perundingan Malino ini.

Murid kesayangan pengasuh PP AI Mutacin Pancasila Sak. ti, Katen, KH Muslim Rifai Imampuro alias Mbah Lim, ini juga menekankan pentingnya mengusung isu kebangsaan, karena bisa menyatukan keragaman masyarakat negeri ini. 'Apapun agamanya, mereka iku bongso deve (bangsa kita sendiri, red.): tandas anggota komisi dialog antar agama Asian Conterence Religion on Peoce (ACRP) ini. "Y

Picture 1. An Example of Materials Being Used

\section{Limited Trial and Model Revision}

The result of the model development was trialed limitedly to the 21 BIPA first semester students by applying the preliminary product into the lecturing activities. Other than that, the trial's result is also going to be tested through students' Bahasa Indonesia competencies after the lecturing activities. Before the trial is done, pre-test is held to figure out students' ability to fill in the answer sheet with these indicators: 
Table 3. Rating Indicators

\begin{tabular}{|c|c|c|c|c|c|}
\hline Competency & Materials & Indicator & $\begin{array}{l}\text { Question } \\
\text { form }\end{array}$ & $\begin{array}{l}\text { Question } \\
\text { number }\end{array}$ & Worth \\
\hline $\begin{array}{l}\text { K.1 Students are able to } \\
\text { understand and applicate } \\
\text { paragraph structure in } \\
\text { Bahasa Indonesia to } \\
\text { analyze texts in Bahasa } \\
\text { Indonesia }\end{array}$ & Paragraph & 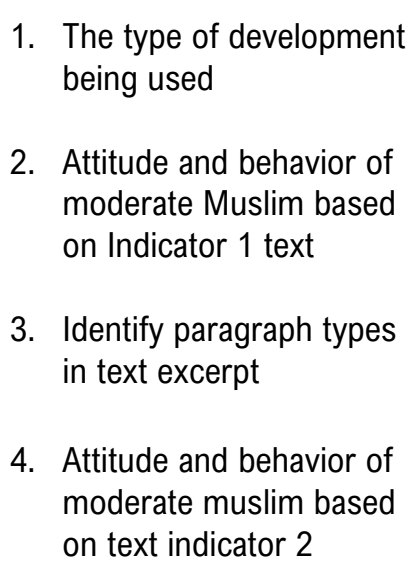 & $\begin{array}{l}\text { Cognitive } \\
\text { test. }\end{array}$ & $\begin{array}{l}3 \\
4\end{array}$ & 20 \\
\hline $\begin{array}{l}\text { K.2. Students are able to } \\
\text { identify and to map } \\
\text { religious values based on } \\
\text { moderate Islam } \\
\text { perspectives in texts } \\
\text { written in Bahasa } \\
\text { Indonesia. }\end{array}$ & & $\begin{array}{l}\text { 5. Finding the conclusion of } \\
\text { the paragraph. } \\
\text { 6. Religious attitude which } \\
\text { is depicted in indicator } 5 \\
\text { 7. Ordering sentences to } \\
\text { make paragraphs that } \\
\text { are grammatically } \\
\text { correct } \\
\text { 8. The religious freedom in } \\
\text { text indicator } 7 \text { is a form } \\
\text { of pluralistic culture } \\
\text { 9. Finding sentences which } \\
\text { are not coherent in the } \\
\text { paragraph. } \\
\text { 10. Realizing that human } \\
\text { beings are all the same } \\
\text { no matter their religion } \\
\text { text indicator } 9 \text { is a form } \\
\text { of pluralistic culture. }\end{array}$ & & 20 & $\begin{array}{l}20 \\
20 \\
20\end{array}$ \\
\hline
\end{tabular}

Table 3 shows five indicators which are related to students' understanding of moderate muslim culture, and each indicator's highest value is ten. The ability to understand moderate muslim culture before having the lessons were low; it was about less than 75 . The most mistakes made were on choosing the attitude and behavior represent moderate muslim culture. Almost all of the students were less precise in determinig and differentiating between exclusivism, inclusivism, pluralism or pararelism.

To get the trial's result, the next step was to do a post-test with the use of cognitive assessment. The students' study result was compared to the pre-test's result and then was analyzed with the paired-sample T-test formula. The analysis that was going to be done was using SPSS software version 11.5. 
The result of the comparison between students' moderate muslim culture cognitive understanding in the pre-test and the post-test is as below:

\section{Paired Samples Statistics}

\begin{tabular}{llllll}
\hline & & & & \multicolumn{2}{l}{ Std. Error } \\
& & Mean & N & Std. Deviation & Mean \\
\hline Pair 1 & Pre-Test & 63.33 & 21 & 12.780 & 2.789 \\
& Post-Test & 79.57 & 21 & 5.688 & 1.241 \\
\hline
\end{tabular}

\section{Paired Samples Correlations}

\begin{tabular}{lllll}
\hline & & N & Correlation & Sig. \\
\hline Pair 1 & Pre-Test \& Post-Test & 21 & .554 & .009 \\
\hline
\end{tabular}

The data from table 'Paired Sample Statistics' and 'Paired Samples Correlations' show that the average value gained from 21 students before the lesson and using preliminary product was 63.33, and the average value after the lesson was 79.57 , with the standard deviation before the lesson as 12.780 , and after the lesson as 5.688 . While for the standard error of mean before the lecture was 2.789 and after the lecture was 1.241. Based on the average value comparison which was gained in between, the result was as follows: before using the model, the average data gained was 63.33 , and it was 79.57 after the lecturer based on the preliminary product which has been arranged before. Therefore, there was a significant student's improvement in the competency related to their understanding of moderate Muslim culture in Indonesia.

The paired samples correlations show that there is a significant correlation between students' achievement before and after the lesson, which is: 0.554 with a significant degree as much as 0.009 . This data gives an important clue that the use of the developed model in the lecturing activity gives a significant contribution to improve students' competency.

\section{Model Testing}

Based on the limited trial which has been done before, suggestions were obtained based on the observation of lecturer's performance. The observation was done to find out strength and weakness, as well as mistakes and deviation made by the lecturers. By that, the problems arise were not on the trial model draft, but on the lecturers' performance. One of the fundamental problems is that lecturers were not used to include the national culture that was related to the religious dynamics in Indonesia. Therefore, mistakes often happened and deviation was emerged. To prevent the problem from arising again in a broader trial scope, the researchers were discussing first especially in relation to the moderate muslim in Indonesia, ideology, movement, and values that stick to their attitude and behavior.

In the model testing, the trial model used in lecturing activities was expanded because it was understood to be representative enough. To measure the result of the model trial, testing was done with experimental method. In the implementation, the test used twosample group; they were: control group and experiment group. The study result which was gained by students in the control group was compared with the result from the experiment 
group and then analyzed with the independent samples t-test formula. The analysis process was planned to use SPSS software version 11.5.

In the experiment group, they were BIPA students in the third year, and the control group consists of students in the second year. The evaluation of the students' achievement of the two groups, the following data was obtained:

\section{Group Statistics}

\begin{tabular}{llllll}
\hline & Group & N & Mean & Std. Deviation & Std. Error Mean \\
\hline Achievement & Experimental group & 11 & 83.64 & 3.233 & .975 \\
& Control group & 11 & 74.09 & 3.015 & .909 \\
\hline
\end{tabular}

Independent Samples Test

\begin{tabular}{|c|c|c|c|c|c|c|c|c|c|c|}
\hline & & \multicolumn{2}{|c|}{$\begin{array}{l}\text { Levene's } \\
\text { Test for } \\
\text { Equality of } \\
\text { Variances }\end{array}$} & & & \multicolumn{5}{|c|}{ t-test for Equality of Means } \\
\hline & & \multirow[t]{2}{*}{$\mathrm{F}$} & \multirow[t]{2}{*}{ Sig. } & \multirow[t]{2}{*}{$\mathrm{t}$} & \multirow[t]{2}{*}{ Df } & \multirow{2}{*}{$\begin{array}{l}\text { Sig. } \\
(2- \\
\text { tailed })\end{array}$} & \multirow{2}{*}{$\begin{array}{l}\text { Mean } \\
\text { Diffe- } \\
\text { rence }\end{array}$} & \multirow{2}{*}{$\begin{array}{l}\text { Std. } \\
\text { Error } \\
\text { Diffe- } \\
\text { rence }\end{array}$} & \multicolumn{2}{|c|}{$\begin{array}{l}95 \% \text { Confidence } \\
\text { Interval of the } \\
\text { Difference }\end{array}$} \\
\hline & & & & & & & & & Lower & Upper \\
\hline \multirow[t]{2}{*}{$\begin{array}{l}\text { Achieve } \\
\text { ment }\end{array}$} & $\begin{array}{l}\text { Equal variances } \\
\text { assumed }\end{array}$ & .295 & .593 & 7.161 & 20 & .000 & 9.55 & 1.333 & 6.765 & 12.326 \\
\hline & $\begin{array}{l}\text { Equal variances } \\
\text { not assumed }\end{array}$ & & & 7.161 & 19.903 & .000 & 9.55 & 1.333 & 6.764 & 12.327 \\
\hline
\end{tabular}

The number of students in the experiment group and control group was 11. The above table shows that the average achievement in the experiment group was 83.64, with the deviation standard 2.233. While for the students from the control group, the average achievement was 74.09 and the deviation standard was 3.015. The data also gave an important clue that the students' achievement average is higher compare to the average student's achievement who were conventionally taught. It can be seen from the mean difference that was 9.55 , which was taken from 83.64 - 74.09. As well as with the P-value which was 0.593 and it was bigger than $>\alpha(0.05)$. This clearly shows that there is a significant difference between students' achievement who followed the lesson using a developed model and student achievement who followed conventional lessons.

Therefore, the expended trial strengthens the important meaning of the limited trial result. The implementation of lecturing model, which integrated moderate Muslim culture immersion strategy into Bahasa Indonesia, gave a significant contribution to students' achievement. The students has significant competence in understanding moderate Islam culture in Indonesia which relates to the religious ideology, movement, and value that shapes their attitude and behavior. Therefore, this model shall be developed by the lecturers who are capable of teaching Bahasa Indonesia module abroad. 


\section{Conclusion}

BIPA learning by immersing moderate muslim culture into Bahasa Indonesia becomes a real need at this time, especially in the countries with non-muslim population majority. A series of radicalism and terrorism action which happened in Indonesia has shaped the point of view of foreign students abroad that Indonesia's beauty as a multi-religious country is almost disappeared. This can implicate the foreign people's motivation to decrease to learn Bahasa Indonesia and to know deeper about national culture.

The immersion of moderate muslim culture into the BIPA program has become the software to change foreign students' point a view towards Indonesia. Based on the learning materials given, they found new facts that they had never known before. That religious life is loaded with inclusive, tolerant, or pararelis attitude and behavior. Indonesian Islam face is not as what they think before: anti-democracy, anti-western, and discriminative towards minority religion.

Through this limited trial and the extended trial, the conclusion is gained that lecturing model which immersing the moderate muslim culture into the Bahasa Indonesia, was succeeded in improving BIPA students' understanding of moderate muslim culture. Students were successfully improving their competencies in understanding the inclusive, pluralistic and parapelist attitude and behavior which is basically the mainstream religious culture in Indonesia.

\section{Acknowledgment}

N/A

\section{References}

Adnan, Z. (2016). Discourse War between the Indonesian Government and the Indonesian Radicals. Australian Folklore, 31.

Affandi, R. M. T., Dermawan, W., \& Alam, G. N. (2019). In Refer to Societal Security Dealing with the Radicalisation in West Java, Indonesia. Central European Journal of International \& Security Studies, 13(4).

Ariani, N. M. (2019). Strategi Pengenalan Nilai-Nilai Budaya Lokal Dalam Pemelajaran Bahasa Indonesia Bagi Penutur Asing (BIPA). Seminar Nasional Inovasi Dalam Penelitian Sains, Teknologi Dan Humaniora-InoBali, 1085-1092.

Azwar, W. (2018). The Resistance of Local Wisdom Towards Radicalism: The Study of the Tarekat Community of West Sumatra, Indonesia. Pertanika Journal of Social Sciences \& Humanities, 26(1).

Barnhisel, G. (2015). Cold War Modernists, Art, Literature, and American Cultural Diplomacy. New York: Columbia University Press.

Borg, W. R., \& Gall, M. D. (1983). Educational Research: An Introduction. New York: Longman.

Darmayanti, N. (2013). Pengajaran Bahasa di Warsawa: Suatu Bentuk Diplomasi-Budaya Indonesia di Polandia. Prosiding dan Makalah Kongres Bahasa Indonesia X (p. 7). Jakarta: Badan Pengembangan dan Pembinaan Bahasa - Kementerian Pendidikan dan Kebudayaan.

Depdiknas. (2008). Panduan Pengembangan Bahan Ajar. Jakarta: Departemen Pendidikan Nasional. 
Diplomasi Seni. (2010, August 15). Koran Tempo, p. A7.

Fealy, G. (2004). Islamic radicalism in Indonesia: The faltering revival? Southeast Asian Affairs, 2004(1), 104-121.

Gumilar, D. T. (2016, January 29). (J. Alfin, Interviewer)

Kusuma, A. (2018). Tantangan dan Strategi Pemelajaran BIPA Bermuatan Nilai Karakter Profetik. Pertemuan IImiah Bahasa Dan Sastra Indonesia (PIBSI) 2018.

Palandi. (2016, January 27). (J. Alfin, Interviewer)

Purwiyanti, Y., Suwandi, S., \& Andayani, A. (2017). Pengembangan Kompetensi Percakapan Pemelajar Bahasa Indonesia Penutur Asing Dengan Strategi Simulasi Percakapan (Permainan Peran Dan Sosio-Drama). Proceedings Education and Language International Conference, 1(1).

Rachman, B. M. (2004). Islam Pluralis, Wacana Kesetaraan Kaum Beriman. Jakarta: Raja Grafindo Persada.

Rivai, O. S., Mariani, A., Neswita, \& Saptawuryandari, N. (2010). Pemetaan Pengajaran Bahasa Indonesia Bagi Penutur Asing (BIPA) di Asia. Jakarta: Pusat Bahasa Kementerian Pendidikan Nasional.

Rosendorf, N. M. (2000). Social and Cultural Globalization: Concepts, History, and America's Role. In J. S. Nye Jr., \& J. D. Donahue, Governance in A Globalizing World (p. 126). Washington, D.C.: The Brookings Institution.

Sari, R. D. P., Suwandi, S., \& St Y, S. (2017). Ekskursi Sebagai Strategi Belajar Bahasa Indonesia Bagi Penutur Asing (BIPA) Dalam Masyarakat Ekonomi Asean (MEA). Proceedings Education and Language International Conference, 1(1).

Sodiq, I., \& Astuti, T. M. P. (2019). Radicalism: The Santri Perspective in Rural Java. International Conference on Rural Studies in Asia (ICoRSIA 2018).

Stelmachowska, D. M. (2016, January 28). (J. Alfin, Interviewer)

Sukmadinata, N. S. (2013). Metode Penelitian Pendidikan. Bandung: Remaja Rosdakarya. 